\title{
EFEKTIFITAS TUMBUHAN ENCENG GONDOK (EICHORMONIA CRASSIPES) SEBAGAI FITOREMEDIASI DALAM MENURUNKAN KADAR BESI (Fe), TIMAH HITAM (Pb), MANGAN (Mn) PADA LEACHATE TPA
}

\author{
Septiana Suryanti, Yusmidiarti, Jubaidi \\ Politeknik Kesehatan Kementerian Kesehatan Bengkulu, Jurusan Kesehatan Lingkungan, \\ Jalan Indragiri Nomor 3 Padang Harapan Bengkulu \\ e-mail : septianasuryanti@yahoo.co.id
}

\begin{abstract}
This study aims at knowing the difference in decreased levels of iron (Fe), lead (Pb), and manganese $(\mathrm{Mn})$ in leachate before and after treatment.

Research used a true experimental design with pre-post test design. The amount of leachate that is used in each treatment is 10 liters of leachate and $1 \mathrm{~kg}$ of water hyacinth, and do in 3 times repetition. Analysis of the was tested using One Way ANOVA test followed by LSD (Least Significance Difference).

The results showed that there were significant differences in the use of water hyacinth in the leachate decreased levels of iron $(\mathrm{Fe})$, lead $(\mathrm{Pb})$, and manganese $(\mathrm{Mn})$ with a value of $\rho=0.000$. Research results before treatment (pre-test) levels $\mathrm{Fe}=6.30 \mathrm{mg} / 1$, after treatment (post-test) $\mathrm{Fe}=$ $0.25 \mathrm{mg} / 1$, before treatment (pre-test) value $\mathrm{Pb}=2.90 \mathrm{mg} / 1$, after treatment (post-test) and $\mathrm{Pb}=$ 0.33 before treatment (pre-test) the value of $\mathrm{Mn}=2.68 \mathrm{mg} / \mathrm{l}$, after treatment (post-test) $\mathrm{Mn}=0.08$ $\mathrm{mg} / \mathrm{l}$. It is known that the ability of water hyacinth weighing $1 \mathrm{~kg}$ with a time of 6 days is more effective than water hyacinth 2 days and 4 days in the lower levels of iron $(\mathrm{Fe})$, lead $(\mathrm{Pb})$ and manganese $(\mathrm{Mn})$ in the leachate.

It can be concluded that water hyacinth could reduce levels of iron $(\mathrm{Fe})$, lead $(\mathrm{Pb})$ and manganese $(\mathrm{Mn})$ in the leachate with contact time 6 days.
\end{abstract}

Key Words: Water Hyacinth, decrease levels of iron (Fe), quits (Pb) and Manganese (Mn)

\begin{abstract}
Abstrak : Penelitian ini bertujuan diketahuinya perbedaan penurunan kadar besi (Fe), timah hitam $(\mathrm{Pb})$, dan mangan $(\mathrm{Mn})$ pada leachate sebelum dan sesudah perlakuan.

Desain penelitian menggunakan true eksperimen dengan rancangan pre-post test. Jumlah leachate yang digunakan pada setiap perlakuan adalah 10 liter leachate dan $1 \mathrm{~kg}$ enceng gondok, dan dilakukan sebanyak 3 kali pengulangan. Analisis data dapat diuji menggunakan uji One Way Anova yang diteruskan dengan uji LSD (Least Significance Difference).

Hasil penelitian menunjukakan bahwa ada perbedaan yang bermakna pada leachate menggunakan enceng gondok pada penurunanan kadar besi $(\mathrm{Fe})$, timah hitam $(\mathrm{Pb})$, dan mangan $(\mathrm{Mn})$ dengan nilai $\rho=0,000$. Hasil Penelitian sebelum perlakuan (pre test) kadar $\mathrm{Fe}=6,30 \mathrm{mg} / \mathrm{l}$, setelah perlakuan (post test) $\mathrm{Fe}=0,25 \mathrm{mg} / \mathrm{l}$, sebelum perlakuan (pre test) nilai $\mathrm{Pb}=2,90 \mathrm{mg} / \mathrm{l}$, setelah perlakuan (post test) $\mathrm{Pb}=0,33$ dan sebelum perlakuan (pre test) nilai $\mathrm{Mn}=2,68 \mathrm{mg} / \mathrm{l}$, setelah perlakuan (post test) $\mathrm{Mn}=0,08 \mathrm{mg} / \mathrm{l}$. Maka diketahui kemampuan enceng gondok seberat $1 \mathrm{~kg}$ dengan waktu 6 hari lebih efektif dibandingkan dengan enceng gondok 2 hari dan 4 hari dalam menurunkan kadar besi $(\mathrm{Fe})$, timah hitam $(\mathrm{Pb})$ dan mangan $(\mathrm{Mn})$ pada leachate.

Dapat disimpulkan bahwa enceng gondok mampu menurunkan kadar besi $(\mathrm{Fe})$, timah hitam $(\mathrm{Pb})$ dan mangan $(\mathrm{Mn})$ pada leachate dengan lama waktu kontak 6 hari.
\end{abstract}

\section{Kata Kunci : Enceng Gondok, Penurunan Kadar Besi (Fe), Timah Hitam (Pb) dan Mangan (Mn)}

Sampah pada awalnya belum menjadi masalah. Namun, seiring bertambahnya jumlah penduduk dan dengan keterbatasan ruang yang ada, maka sampah berkembang menjadi masalah serius, sampah dapat berfungsi sebagai tempat berkembangnya vektor penyakit menular dan menciptakan pemandangan yang kurang menyenangkan. Disamping itu, sampah dapat menimbulkan pencemaran udara, air, maupun tanah yang secara langsung berpengaruh terhadap kesehatan lingkungan (Wijayanti, 2002). 
Pengolahan sampah di Kota Bengkulu sebagian dikelola oleh dinas kebersihan selebihnya dikelola secara swakelola oleh masyarakat dengan cara ditimbun dan dibakar. Sarana persampahan yang ada berupa gerobak sampah, TPS, container dan alat pengangkut sampah berupa truk.

Asumsi timbunan sampah untuk kota berkelas sedang sebesar 3 liter/orang/hari, maka kebutuhan komponen persampahan Kota Bengkulu dengan jumlah penduduk 460.772 jiwa, sampah yang terangkut $66,90\left(\mathrm{~m}^{3} /\right.$ hari $)$, dan perkiraan timbunan sampah total $1.192,32\left(\mathrm{~m}^{3} /\right.$ hari $)$. Sehingga banyaknya sampah yang belum terlayani adalah $1.145,42\left(\mathrm{~m}^{3} /\right.$ hari). Untuk produksi limbah cair, setiap manusia diasumsikan memproduksi limbah cair sejumlah 0,2 liter/orang/hari, angka ini merupakan kebutuhan ideal dari setiap penduduk pada kelas kota berkelas sedang sehingga didapatkan asumsi produksi di Kota Bengkulu ini sejumlah 92,154 liter/hari. Sehingga, menimbulkan banyak leachate dari tumpukan sampah yang mengakibatkan banyak pencemaran pada tanah (Profil Dinas Kebersihan dan Pertamanan, 2010).

Leachate banyak mengandung bahanbahan organik terlarut serta ion-ion anorganik dalam konsentrasi tinggi, sehingga leachate potensial menimbulkan pencemaran terhadap sumber air tanah dan air permukaan, tetapi untuk mengolah leachate tidaklah mudah karena dibutuhkan proses yang rumit dan biaya yang tidak sedikit. Leachate juga menimbulkan berbagai macam penyakit, karena mempunyai unsur kimia yang tinggi, seperti kulit gatal, panas, dan merah merupakan gejala Dermatitis yang merupakan respon kulit terhadap agen-agen yang beraneka ragam. Respon tersebut biasa berhubungan dengan alergi. Dermatitis kontak adalah Dermatitis (peradangan kulit) yang disertai adanya edema interseluler pada epidermis karena kulit berinteraksi dengan bahan-bahan kimia yang berkontak atau memajani kulit, bahan-bahan tersebut dapat bersifat toksik atau alergik (Wijayanti, 2002).
Kadar Besi (Fe) dalam air yang melebihi ambang batas akan menimbulkan gangguan paru-paru, warna, karat, bakteri, rasa dan bau pada sistem distribusi air (Sanropie, 2005). Keputusan Menteri Negara Lingkungan Hidup Nomor KEP51/MENLH/10/1995 tentang Baku Mutu Limbah Cair yaitu kadar Besi (Fe) sebesar $5 \mathrm{mg} / \mathrm{l}$, timah hitam $(\mathrm{Pb})$ sebesar $1 \mathrm{mg} / \mathrm{l}$, dan mangan (Mn) sebesar $2 \mathrm{mg} / \mathrm{l}$. Leachate juga mengandung unsur-unsur hara sekunder dan mikro seperti Kalsium (Ca), Magnesium (Mg), Mangan (Mn), Khlor $(\mathrm{Cl})$, Timah hitam $(\mathrm{Pb})$, Besi $(\mathrm{Fe})$ dan mempunyai $\mathrm{pH}$ yang relatif netral (Badrus, 2006) .

Tumbuhan Enceng Gondok (Eichornia crassipes) telah lama digunakan untuk proses penjernihan air. Mekanisme yang terjadi adalah proses koagulasi menggunakan ekstrak tumbuhan yang bersifat koagulan. Enceng Gondok ini digunakan untuk pengolahan air limbah secara tradisional. Di daerah hilir banyak saluransaluran air yang dipenuhi Enceng Gondok, yang secara alami dapat membersihkan air limbah. Tanaman air lain seperti kapukapu (Pistia stratiotes) dan kiambang (Salvinia natans) dapat dimanfaatkan untuk pengolahan air limbah. Akhir-akhir ini tanaman alang-alang juga dimanfaatkan untuk pengolahan air limbah menggunakan sistem wetland (lahan basah), tetapi Enceng Gondok merugikan lingkungan dan sumber daya air karena pertumbuhan Enceng Gondok yang begitu cepat bisa menutupi seluruh perairan, akibatnya jumlah cahaya yang masuk ke dalam air semakin berkurang dan tingkat kelarutan oksigen pun akan berkurang. Selain itu Enceng Gondok juga dapat mengganggu lalu lintas di perairan, terutama bagi para nelayan karena perahunya sering terjebak dan sulit bergerak akibat pertumbuhan Enceng Gondok yang menyebar ke seluruh permukaan air (Ratnani, 2011).

Penelitian ini akan memanfaatkan tumbuhan Enceng Gondok sebagai fitoremediasir pada penanganan leachate. Tumbuhan Enceng Gondok dipilih karena 
dapat digunakan sebagai sarana penanganan limbah cair, selain itu Enceng Gondok mempunyai kemampuan untuk menyerap logam-logam berat termasuk kadar Besi $(\mathrm{Fe})$, Mangan $(\mathrm{Mn})$ dan Timah hitam $(\mathrm{Pb})$ dengan cara melakukan penyerapan melalui permukaan sel akar, karena adanya proses adsorbs (Jamahir, 2012).

Pengolahan leachate menggunakan Enceng Gondok merupakan satu alternatif pemecahan masalah pengolahan limbah cair yang sederhana. Yang terpenting yaitu mengendalikan dan mengurangi beban pencemaran terhadap sumber air bersih oleh adanya pergerakan leachate dari kegiatan penimbunan sampah secara open dumping dan pembuangan leachate ke badan air secara langsung (Hardyanti, 2007).

\section{BAHAN DAN CARA KERJA}

Penelitian ini merupakan jenis penelitian true eksperimen atau eksperimen sesungguhnya dengan rancangan "Pre Post Test" dianalisis secara deskriptif dan analitik (Notoatmojo, 2010). Adapun desain penelitian yang digunakan adalah 1 kontrol dengan 3 kelompok perlakuan. Sampel penelitian ini yaitu 120 liter leachate dan 1 kg Enceng Gondok. Penelitian ini dilakukan di Laboratorium Politeknik Kesehatan Kementerian Kesehatan Bengkulu April 2013.

Alat yang digunakan dalam penelitian ini adalah ember penampung untuk air leachate, jerigen 20 liter, timbangan, spektro photometer dan gayung. Sedangkan bahannya adalah Enceng Gondok $1 \mathrm{~kg}$, air bersih 20 liter, dan air leachate 10 liter.

Alat dan bahan yang akan dipakai dipersiapkan terlebih dahulu selanjutnya melakukan aklimitasasi, bagi tumbuhan Enceng Gondok yang akan digunakan dengan cara menanam di dalam air sumur selama 6 hari tanpa pergantian air. Setelah itu di lakukan penambahan air leachate secara bertahap mulai dari $20 \%, 50 \%$, dan $80 \%$.
Untuk pengambilan sampel dipersiapkan alat dan bahan. Disiapkan jerigen 20 liter dan gayung untuk mengambil sampel, kemudian air leachate dimasukkan ke dalam ember kontrol dan ember perlakuan sebanyak 10 liter, pada ember perlakuan di tambahkan Enceng Gondok seberat $1 \mathrm{~kg}$ dan ember kontrol tidak di tambahkan Enceng Gondok dan didiamkan selama 2 hari, 4 hari dan 6 hari. Selanjutnya diambil air leachate sebanyak $200 \mathrm{ml}$ dari masing-masing ember kontrol dan perlakuan untuk diperiksa kadar Besi $(\mathrm{Fe})$, timah hitam $(\mathrm{Pb})$, dan mangan $(\mathrm{Mn})$. Di Laboratorium Politeknik Kesehatan Kementerian Kesehatan Bengkulu.

\section{HASIL}

Hasil penelitian disajikan dalam analisis univariat dari setiap variabel independen dan dependen. Penyajian dilanjutkan dengan hasil analisis bivariat yang bertujuan untuk melihat perbedaan variabel independen dengan variabel dependen.

\section{Analisis Univariat}

Uji laboratorium dilakukan di Laboratorium Terpadu Politeknik Kesehatan Kementerian Kesehatan Bengkulu terhadap sampel pre test, post test 2 hari, post test 4 hari, dan post test 6 hari, maka di peroleh hasil seperti gambar 1 .

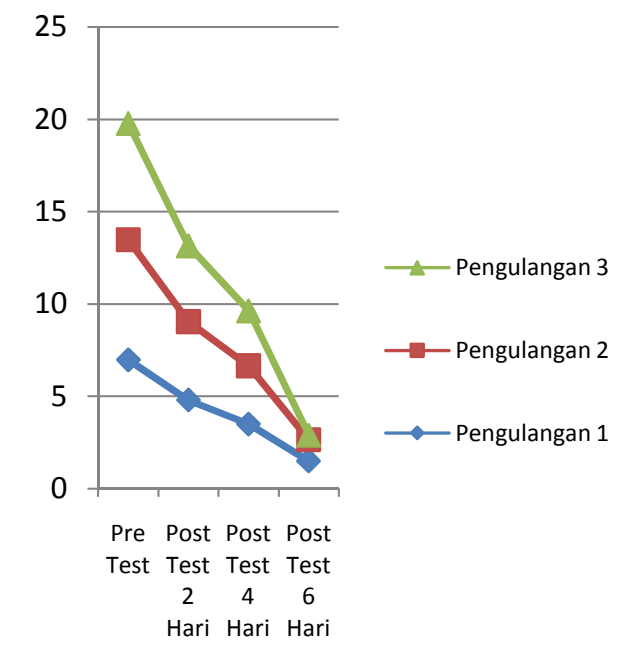

Gambar 1 Hasil Analisis Nilai Kadar Besi (Fe) dalam 3 Kali Pengulangan 
Gambar 1 diketahui nilai kadar Besi (Fe) mengalami penurunan dari masingmasing pengulangan, sebelum perlakuan (Pre Test) 6,98, 6,80, 6,30, setelah perlakuan (Post Test) 2 hari menjadi 4,80, 4,25, 4,10, setelah perlakuan (Post Test) 4 hari menjadi $3,50,3,15,2,98$, setelah perlakuan (Post Test) 6 hari menjadi 1,50, $1,15,0,25$.

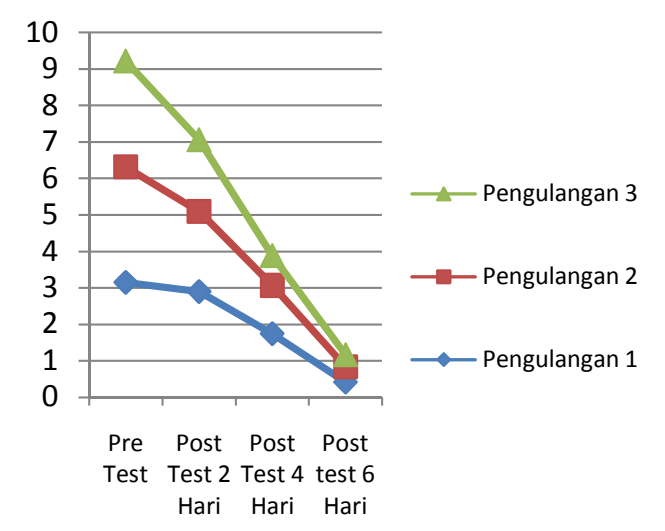

Gambar 2 Hasil Analisis Nilai kadar Timah Hitam (Pb) Dalam 3 kali pengulangan

Gambar 2 diketahui nilai kadar timah hitam $(\mathrm{Pb})$ mengalami penurunan dari masing-masing 3 kali pengulangan, sebelum perlakuan (Pre Test) 3,15, 3,17, 2,90, setelah perlakuan (Post Test) 2 hari menjadi 2,90, 2,20, 1,96, setelah perlakuan (Post Test) 4 hari menjadi 1,75, 1,32, 0,82, setelah perlakuan (Post Test) 6 hari menjadi $0,42,0,41,0,33$.

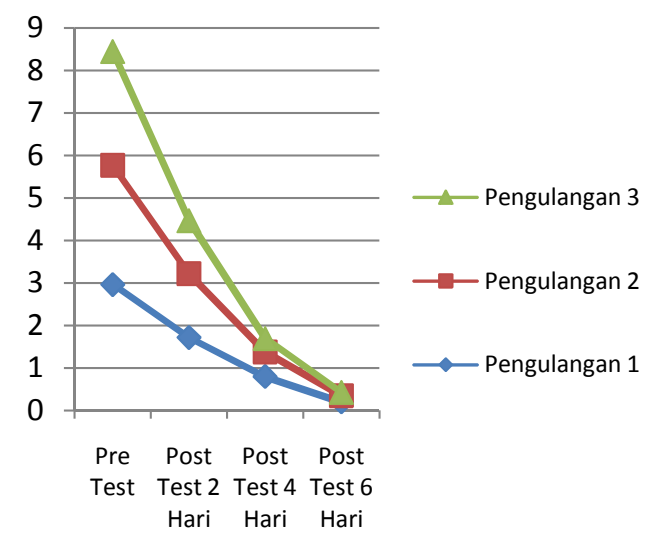

Gambar 3 Hasil Analisis Nilai Kadar Mangan (Mn) Dalam 3 Kali Pengulangan
Gambar 3 diketahui nilai kadar mangan (Mn) mengalami penurunan dari masing-masing 3 kali pengulangan, sebelum perlakuan (Pre test) 2,97, 2,80, 2,68, setelah perlakuan (Post Test) 2 hari menjadi 1,72, 1,50, 1,25, setelah perlakuan (Post Test) 4 hari menjadi 0,80, 0,58, 0,32, setelah perlakuan (Post Test) 6 hari menjadi $0,20,0,15,0,08$.

\section{Analisis Bivariat}

Uji varian satu jalan atau One Way Anova digunakan untuk menguji perbedaan antara tiga atau lebih kelompok sampel yang bebas dengan Uji One Way Anova. Analisis bivariat dalam penelitian ini dilakukan untuk mengetahui perbedaan penurunan kadar Besi $(\mathrm{Fe})$, timah hitam $(\mathrm{Pb})$, dan mangan $(\mathrm{Mn})$ pada leachate dengan menggunakan Enceng Gondok 1 $\mathrm{kg}$ dan lama kontak 2 hari, 4 hari, dan 6 hari. Untuk mengetahui perbedaannya maka dilakukan uji statistik dengan pembacaan yaitu $\mathrm{p}<0,05$ sebagaimana pada tabel 1:

Tabel 1 Uji One Way Anova Nilai Penurunan Kadar Besi (Fe), Timah Hitam (Pb) dan Mangan (Mn) Leachate Menggunakan Enceng Gondok dengan Setiap Variasi Waktu Kontak dan 3 Kali Pengulangan

\begin{tabular}{lcccc}
\hline $\begin{array}{c}\text { Variabel } \\
\text { Perlakuan }\end{array}$ & Mean & SD & $95 \%$ CI & P value \\
\hline Kadar Besi & & & & \\
Pre test & 6,59 & 0,35 & $5,72-7,46$ & \\
2 Hari & 4,38 & 0,37 & $3,47-5,29$ & \\
4 Hari & 3,25 & 0,22 & $2,71-3,79$ & 0,000 \\
6 Hari & 0,96 & 0,64 & $0,63-2,57$ & \\
Kadar Timah Hitam $(\mathrm{Pb})$ & & \\
Pre test & 3,07 & 0,15 & $2,69-3,45$ & 0,000 \\
2 Hari & 2,35 & 0,48 & $1,14-3,57$ & \\
4 Hari & 1,29 & 0,46 & $0,14-2,45$ & \\
6 Hari & 0,30 & 0,19 & $0,18-0,78$ & \\
Kadar Mangan $(\mathrm{Mn})$ & & & \\
Pre test & 2,82 & 0,14 & $2,45-3,17$ & \\
2 Hari & 1,49 & 0,23 & $0,90-2,07$ & 0,000 \\
4 Hari & 0,57 & 0,24 & $0,03-1,16$ & \\
6 Hari & 0,14 & 0,06 & $0,006-0,29$ & \\
& & & & \\
\hline
\end{tabular}


Tabel 1 uji anova 1 jalan dapat diketahui nilai $\rho=0,000<0,05$ karena itu dapat diartikan bahwa secara statistik Ho ditolak dan Ha diterima, sehingga ada perbedaan efektifitas lama waktu kontak terhadap penurunan kadar Besi $(\mathrm{Fe})$ pada leachate.

Pada uji anova 1 jalan pemeriksaan kadar timah hitam $(\mathrm{Pb})$ dapat diketahui nilai $\rho=0,000<0,05$ karena itu dapat diartikan bahwa secara statistik Ho ditolak dan Ha diterima sehingga ada perbedaan efektifitas lama waktu kontak terhadap penurunan kadar timah hitam $(\mathrm{Pb})$ pada leachate.
Pada uji anova 1 jalan pemeriksaan Mangan (Mn) dapat diketahui nilai $\rho=$ $0,000<0,05$ karena itu dapat diartikan bahwa secara statistik Ho ditolak dan $\mathrm{Ha}$ diterima, sehingga ada perbedaan efektifitas lama waktu kontak terhadap penurunan kadar mangan $(\mathrm{Mn})$ pada leachate.

Untuk mengetahui perbedaan efektifitas lama waktu kontak terhadap penurunan Kadar Besi $(\mathrm{Fe})$, timah hitam $(\mathrm{Pb})$, dan mangan $(\mathrm{Mn})$ leachate menggunakan Enceng Gondok dengan variasi waktu kontak 2 hari, 4 hari, dan 6 hari. Maka dilakukan uji LSD (Least Significance Difference). Hasil uji LSD dapat dilihat pada tabel 2:

Tabel 2 Hasil Uji Lanjut LSD Pre test (Sebelum perlakuan) dan Post test (Setelah perlakuan) Kadar Besi (Fe), Kadar Timah Hitam (Pb) dan Kadar Mangan (Mn)

\begin{tabular}{|c|c|c|c|c|c|c|c|}
\hline \multicolumn{2}{|c|}{ Perlakuan } & \multicolumn{3}{|c|}{ Rata-Rata Beda } & \multicolumn{3}{|c|}{$\mathrm{P}$ value } \\
\hline & & $\begin{array}{c}\text { Kadar Besi } \\
(\mathrm{Fe})\end{array}$ & $\begin{array}{c}\text { Kadar } \\
\text { Timah } \\
\text { Hitam }(\mathrm{Pb})\end{array}$ & $\begin{array}{c}\text { Kadar } \\
\text { Mangan } \\
(\mathrm{Mn})\end{array}$ & $\begin{array}{c}\text { Kadar } \\
\text { Besi }(\mathrm{Fe})\end{array}$ & $\begin{array}{c}\text { Kadar } \\
\text { Timah } \\
\text { Hitam }(\mathrm{Pb}\end{array}$ & $\begin{array}{c}\text { Kadar } \\
\text { Mangan } \\
(\mathrm{Mn})\end{array}$ \\
\hline \multirow[t]{3}{*}{ Pre test (Kontrol) } & 2 Hari & 2,21 & 0,72 & 1,32 & 0,000 & 0,040 & 0,000 \\
\hline & 4 Hari & 3,34 & 1,17 & 2,25 & 0,000 & 0,000 & 0,000 \\
\hline & 6 Hari & 5,62 & 2,77 & 2,67 & 0,000 & 0,000 & 0,000 \\
\hline \multirow[t]{2}{*}{2 Hari } & 4 Hari & 1,13 & 1,06 & 0,92 & 0,011 & 0,007 & 0,000 \\
\hline & 6 Hari & 3,41 & 2,05 & 1,34 & 0,000 & 0,000 & 0,000 \\
\hline 4 Hari & 6 Hari & 2,28 & 0,99 & 0,42 & 0,000 & 0,010 & 0,023 \\
\hline
\end{tabular}

Tabel 2 diketahui bahwa adanya perbedaan penurunan kadar Besi $(\mathrm{Fe})$ yang bermakna antara pre test dan post test baik 2 hari, 4 hari dan 6 hari, hal ini dilihat dari $\rho<\alpha$. Antara pre test dengan post test 6 hari nilai $\mathrm{p} 0,000<0,05$. Sehingga ada perbedaan yang bermakna di antara kelompok perlakuan Enceng Gondok dengan waktu 6 hari lebih efektif dibandingkan dengan Enceng Gondok selama 2 hari dan 4 hari.

Adanya perbedaan penurunan kadar timah hitam $(\mathrm{Pb})$ yang bermakna antara pre test dan post test baik 2 hari, 4 hari dan 6 hari, hal ini dilihat dari $\rho<\alpha$. Antara pre test dengan 6 hari nilai $\rho 0,000<0,05$. Sehingga ada perbedaan yang bermakna di antara kelompok perlakuan Enceng Gondok dengan waktu 6 hari lebih efektif dibandingkan dengan Enceng Gondok selama 2 hari dan 4 hari.

Selain itu, diketahui bahwa adanya perbedaan penurunan kadar mangan (Mn) yang bermakna antara pre test dan post test baik 2 hari, 4 hari dan 6 hari, hal ini dilihat dari $\rho<\alpha$. Antara pre test dengan post test 6 hari nilai $\rho 0,000<0,05$. Sehingga ada perbedaan yang bermakna di antara kelompok perlakuan Enceng Gondok dengan waktu 6 hari lebih efektif dibandingkan dengan Enceng Gondok selama 2 hari dan 4 hari.

\section{PEMBAHASAN}

Hasil uji One way Anova diketahui bahwa Enceng Gondok sangat berpengaruh terhadap penurunan kadar Besi (Fe), timah hitam $(\mathrm{Pb})$, mangan $(\mathrm{Mn})$. Pada penelitian ini peneliti membedakan lama waktu kontak (2 hari, 4 hari dan 6 hari) agar dapat digunakan sebagai pembanding pada masing-masing perlakuan dan pre test serta sebagai cara untuk menentukan yang mana lama kontak paling efektif dalam me- 
nurunkan kadar Besi (Fe), timah hitam $(\mathrm{Pb})$, dan mangan $(\mathrm{Mn})$ pada leachate.

Untuk mengetahui perbedaan efektifitas lama waktu kontak terhadap penurunan kadar Besi $(\mathrm{Fe})$, timah hitam $(\mathrm{Pb})$, dan mangan $(\mathrm{Mn})$ pada leachate dengan variasi waktu kontak 2 hari, 4 hari dan 6 hari, maka, dilakukan uji LSD (Least Significance Difference) sehingga diperoleh lama kontak 6 hari paling efektif menurunkan kadar Besi (Fe), timah hitam $(\mathrm{Pb})$, dan mangan $(\mathrm{Mn})$ pada leachate.

Waktu kontak yang lama menentukan proses absorbsi, sehingga semakin lama proses difusi dan penempelan molekul zat terlarut yang terabsorbsi berlangsung lebih baik, sesuai keunggulan Enceng Gondok yang di proses sedemikian rupa sehingga pori-porinya terbuka, dengan demikian akan mempunyai daya serap yang dapat menghilangkan partikel-partikel dalam air dan menurunkan logam berat seperti kadar Besi $(\mathrm{Fe})$, timah hitam $(\mathrm{Pb})$, dan mangan (Mn).

Penelitian ini sejalan dengan penelitian yang dilakukan oleh Hidayat, et.al (2011) yang berjudul efektifitas tanaman Enceng Gondok (Eichormonia crasspies) dalam penurunan kadar Besi $\mathrm{Fe}$ pada leacahte. Pada penelitian ini diketahui bahwa penggunaan tumbuhan Enceng Gondok dapat menurunkan kadar (Fe) dalam jumlah yang besar. Hal ini tergantung dari beratnya Enceng Gondok yang digunakan tetapi pada penelitian ini, Enceng Gondok yang digunakan seberat $200 \mathrm{mg} / \mathrm{l}$ dalam waktu 10 hari, maka dari itu peneliti meneruskan penelitian dari Hidayat, et.al, dengan menggunakan berat Enceng Gondok $1 \mathrm{~kg}$ dalam waktu 2 hari, 4 hari dan 6 hari.

Fitoremediasi Enceng Gondok dapat menurunkan kadar $(\mathrm{Fe}),(\mathrm{Pb})$, dan $(\mathrm{Mn})$ secara bermakna karena pada proses fitoremediasi terjadi penguraian bahan-bahan organik dalam air limbah oleh mikroba yang berbeda di sekitar akar tanaman Enceng Gondok. Mikroba yang berbeda pada akar eceng gondok yaitu Mikroba Rhizosfera memiliki kemampuan untuk me- nguraikan bahan organik yang ada dalam limbah. Sebagaimana yang telah dikemukakan oleh Purwasari (2012), tanaman yang hidup di air seperti Enceng Gondok memiliki Mikroba Rhizosfera pada perakarannya yang mampu menguraikan bahan organik ataupun anorganik.

Penelitian ini menunjukkan adanya perbedaan penurunan kadar Besi $(\mathrm{Fe})$, timah hitam $(\mathrm{Pb})$, mangan $(\mathrm{Mn})$ antara perlakuan Enceng Gondok dengan waktu 2 hari, 4 hari dan perlakuan Enceng Gondok selama waktu 6 hari, dimana waktu Enceng Gondok selama 6 hari lebih efektif dalam menurunkan kadar Besi $(\mathrm{Fe})$, timah hitam $(\mathrm{Pb})$, dan Mangan $(\mathrm{Mn})$ pada leachate dibandingkan dengan waktu Enceng Gondok 2 hari dan 4 hari. Lamanya kontak antara leachate dengan beratnya Enceng Gondok sangat menentukan besar kecilnya penurunan kadar Besi $(\mathrm{Fe})$, timah hitam $(\mathrm{Pb})$ dan mangan $(\mathrm{Mn})$ di dalam leachate karena semakin lama kontak Enceng Gondok, maka akan semakin banyak pula penurunan kadar Besi $(\mathrm{Fe})$, timah hitam $(\mathrm{Pb})$ dan mangan $(\mathrm{Mn})$ yang terdapat dalam leachate.

Hidayat, et.al (2011) Enceng Gondok terbukti mampu menurunkan kadar polutan Timah Hitam $(\mathrm{Pb})$ dan Besi $(\mathrm{Fe})$. Oleh karena itu, di yakini juga mampu menurunkan kadar polutan Merkuri $(\mathrm{Hg})$, Seng $(\mathrm{Zn})$, dan Tembaga $(\mathrm{Cu})$ yang mencemari limbah cair, secara struktur kimia, Merkuri (Hg), Seng ( $\mathrm{Zn})$, dan Tembaga $(\mathrm{Cu})$ termasuk dalam golongan logam berat bersama TImah Hitam $(\mathrm{Pb})$ dan Besi (Fe). Kemampuan Enceng Gondok dalam menyerap logam berat juga telah di lakukan oleh para pakar. Widyanto dan Susilo (2011) melaporkan, dalam waktu 24 jam Enceng Gondok mampu menyerap logam Kadmium (Cd), Merkuri $(\mathrm{Hg})$, dan Nikel (Ni), masing-masing sebesar $1,35 \mathrm{mg} / \mathrm{g}, 1,77 \mathrm{mg} / \mathrm{g}$, dan 1,16 $\mathrm{mg} / \mathrm{g}$ bila logam itu tidak bercampur. Enceng Gondok juga menyerap Kadmium (Cd) $1,23 \mathrm{mg} / \mathrm{g}$, Merkuri $(\mathrm{Hg}) 1,8 \mathrm{mg} / \mathrm{g}$ dan Nikel (Ni) $0,35 \mathrm{mg} / \mathrm{g}$ berat kering apabila logam-logam itu berada dalam 
keadaan tercampur dengan logam lain. Kecepatan dan banyaknya penyerapan di pengaruhi oleh berbagai faktor, misalnya jenis logam/zat pencemar, umur, ukuran tumbuhan dan lamanya kontak berlangsung. Enceng Gondok tidaklah sia-sia diciptakan oleh Tuhan Yang Maha Esa, maupun sebagai penggangu manusia Enceng Gondok dapat dinyatakan sebagai pembersih alami perairan, limbah cair,atau danau terhadap polutan, baik logam berat maupun pestisida atau yang lainnya.

Peneliti hanya menggunakan waktu Enceng Gondok 2 hari, 4 hari dan 6 hari dengan pengulangan masing-masing sebanyak 3 kali. Namun kadar Besi (Fe), Timah Hitam $(\mathrm{Pb})$ dan Mangan (Mn) menurun secara drastis. Maka untuk memperoleh angka penurunan yang lebih maksimal, memerlukan waktu Enceng Gondok yang lebih lama lagi dan untuk menambah keyakinan penelitian akan lebih baik juga apabila pengulangan di lakukan lebih dari 3 kali pengulangan.

\section{KESIMPULAN}

Kadar Besi $(\mathrm{Fe})$ sebelum perlakuan adalah 6,30 $\mathrm{mg} / \mathrm{l}$, setelah perlakuan menggunakan Enceng Gondok $1 \mathrm{~kg}$ adalah $0,25 \mathrm{mg} / \mathrm{l}$, kadar timah hitam $(\mathrm{Pb})$ sebelum perlakuan adalah 2,90 $\mathrm{mg} / \mathrm{l}$ setelah perlakuan menggunakan Enceng Gondok 1 kag adalah 0,33 $\mathrm{mg} / \mathrm{l}$, dan kadar mangan (Mn) sebelum perlakuan 2,68 mg/l setelah

\section{DAFTAR RUJUKAN}

Alex, S (2010). Sampah Organik Menjadi Pupuk Organik. Yogyakarta : Pustaka Baru Press

Damanhuri, 2000. Pengelolaan Sampah. Studik Teknik Lingkungan. Fakultas Teknik Sipil Dan Lingkungan. Bandung

Damandiri, 2003. Pemanfaatan Serbuk Enceng Gondok Untuk Pengelolaan sampah Menjadi Kompos. Politeknik Kemenkes Semarang. Jurnal Kesehatan Lingkungan. Vol. 2 No. 1 Agustus 2003.

Hardyanti, dkk 2007. Fitoremediasi Phospat Dengan Pemanfaatan Enceng Gondok Studi Kasus Pada Limbah Cair Industri Kecil Laundry. Universitas FT Undip dan Politeknik Negeri Semarang. Jurnal Presitipasi Vol. 2 No. 1 Maret 2007, ISSN 1907-187. X perlakuan menggunakan Enceng Gondok 1 $\mathrm{kg}$ adalah $0,08 \mathrm{mg} / \mathrm{l}$

Ada perbedaan yang bermakna terhadap penurunan kadar Besi $(\mathrm{Fe})$, timah hitam $(\mathrm{Pb})$, dan mangan $(\mathrm{Mn})$ pada leachate menggunakan Enceng Gondok dengan lama waktu kontak 2 hari, 4 hari dan 6 hari. Penurunan efektifitas kadar Besi $(\mathrm{Fe})$, timah hitam $(\mathrm{Pb})$, dan mangan (Mn) yang terefektif adalah 6 hari.

Pengelola hendaknya dapat memanfaatkan tumbuhan Enceng Gondok sebagai dalam menurunkan kadar Besi $(\mathrm{Fe}), \mathrm{Pb}$, dan Mn pada leachate di TPA Air Sebakul Kota Bengkulu.

Hendaknya peneliti ini dapat menjadi referensi apabila akan dilakukan penelitian lebih lanjut mengenai cara menurunkan $\mathrm{Fe}$, $\mathrm{Pb}$, dan $\mathrm{Mn}$ pada limbah cair khususnya leachate. Pihak institusi pendidikan juga di harapkan dapat meningkatkan kemampuan mahasiswa mengenai teknologi tepat guna, salah satunya alat untuk menuerunkan kadar $\mathrm{Fe}$, timah hitam $(\mathrm{Pb})$, dan mangan (Mn) pada leachate.

Kepada peneliti selanjutnya agar lebih mengembangkan penelitian ini dengan menggunakan tumbuhan lain yang dapat digunakan sebagai fitoremediasi dalam limbah cair serta perlunya melakukan pemeriksaan mengenai persyaratan kimiawi pada leachate selain kadar Besi $(\mathrm{Fe})$, timah hitam $(\mathrm{Pb})$ dan mangan $(\mathrm{Mn})$.

Jamahir, dkk 2012. Studi Pemanfaatan Serbuk Enceng Gondok teraktirasi NaOH $2 \%$ Sebagai Adsorben terhadap Ion Besi $\left(\mathrm{Fe}^{3+}\right)$ dan Tembaga $\left(\mathrm{Cu}^{2+}\right)$ Dalam Air Sungai Batang Natal. Universitas Sumatra Utara. Jurnal Saintaia Kimia Vol 1, No. 1, 2012.

--------- Notoatmodjo, S (2010). Metodologi Penelitian Kesehatan. Jakarta. Rineka Cipta

Peraturan menteri Kesehatan Nomor. 416/MENKES/PER/IX/1990. Tentang SyaratSyarat Dan Pengawasan Kualitas Air. Jakarta --- Profil Kesehatan Kota Bengkulu 2010 - Profil Dinas Kebersihan dan Pertamanan Kota Bengkulu 2010

Purwasari, dkk 2012. Pengaruh Fitoremediasi Terhadap Fosfat dan Amonia Di Instalasi 
Pengolahan Limbah Cair RSUP DR Sardjito Yogyakarta. Politeknik Kesehatan Kementerian Kesehatan Yogyakarta. Jurnal Kesehatan Lingkungan, Vol. 3, No. 4, Februari 2012

Purwanta, 2007. Tinjauan teknologi Pengolahan Leachate di Tempat Pembuangan Akhir (TPA) Sampah Perkotaan. Badan Pengkajian dan Penerapan Teknologi (BPPT)

Ratnani, dkk 2011. Pemanfaatan Eceng Gondok (Eichormia crissipes) Untuk Menurunkan Kandungan COD, PH, Bau Dan Warna Pada Limbah Cair Tahu. Universitas Wahid Hasyim. Semarang. Jurnal Teknik Kimia, Vol 7, No 1 April 2011

Setyanto, dkk 2011. Pemanfaatan Enceng Gondok Untuk Membersihkan Kualitas Air Sungai Sungai Gadjahwong Yogyakarta. Jurnal teknologi Vol. 4 No. 1 Agustus 2011, ISSN 1979-8415

Widyanto dan Susilo 2011, Enceng Gondok Pembersih Polutan Logam Berat. Jakarta
Wijayanti, 2002. Pemanfaatan Tanaman Enceng Gondok Sebagai Plantfilter Kadar Besi Total Leachate Dalam Tanah. Skripsi Yayasan Lingkungan Hidup. Yogyakarta.

Fahrul, 2001. Studi Pengolahan Air Limbah Domestik Dengan Biofilter Aerasi menggunakan Media Bioball Dan Eceng Gondok (Eichormia crassipes). Istitut Teknologi Lingkungan. Surabaya

Hidayat, dkk 2011. Efektifitas Tanaman Enceng Gondok (Eichormia crassipes) Dalam Penurunan Kadar Besi Fe Pada Leachate. Jurnal Fakultas Kesehatan Masyarakat. Universitas Muhammadiyah Semarang

Badrus, dkk 2006. Kemampuan Penyerapan Enceng Gondok Terhadap Amoniak Dalam Limbah Rumah sakit Berdasarkan Umur dan Lama Kontak. Universitas FT Undip. Jurnal Presipitasi Vol. 2 No. 1 September 2006, ISSN 1907-187 X. 